Apidologie, 1983, 14 (1), 41-57.

\title{
CYTOLOGICAL ANALYSIS OF THE THELYTOKOUS PARTHENOGENESIS IN THE CAPE HONEYBEE (APIS MELLIFERA CAPENSIS ESCHOLTZ)*
}

\author{
Savitri VERMA and Friedrich RUTTNER \\ FB Biologie der Universität Frankfurt, Institut für Bienenkunde \\ D-6370 Oberursel/Ts.
}

\section{SUMMARY}

Laying workers of Apis mellifera capensis EsCHOLTZ producing impaternate offspring are normal diploids with $2 n=32$ chromosomes. During the first maturation division, chromosome pairing, synapsis, chiasmata and diakinesis were observed. Thus a reduction division occurs resulting in a haploid set of 16 chromosomes.

During anaphase II four nuclei are formed, arranged in a line parallel to the egg surface. Later two central nuclei, i.e. the egg pronucleus and the central descendant of the first polar body (second division non-sister nuclei) fuse to form the (diploid) zygote nucleus.

Genetic consequences of the mechanism of automixis are discussed.

\section{INTRODUCTION}

In the honeybee (A.m.) fertilized eggs develop into diploid females or - in case of close inbreeding - into diploid males (zygogenesis), and without fertilization into haploid males (generative or haploid parthenogenesis).

Several research workers, however, have reported the unusual occurence of impaternate females among the male progeny of virgin queens and laying workers (Onions, 1912, 1914; Mackensen, 1943; Gubin and Khalifman, 1951; Tryasko, $1969,1975)$.

The most interesting case is the Cape honeybee (A.m. capensis), where laying worker bees produce nearly exclusively female larvae from which workers and also

(*) With a grant of the Deutsche Forschungsgemeinschaft. 
queens may be reared. The workers of this race possess a developed spermatheca which is devoid of any kind of sperm cell.

Experiments by Mackensen, 1943, Butler, 1954 and Tryasko, 1975 showed that impaternate females are diploid. In A.m. capensis worker bees RUTTNER (1977) obtained several generations without any kind of mating and suggested an automictic type of parthenogenesis. TUCKER (1958), using strains of three different races (ligustica, mellifera, caucasica) and a number of recessive marker genes, suggested that automictic workers are derived from the union of two haploid nuclei, formed by complete meiosis. However, cytological mechanisms were inferred from the segregation of mutant genes, since impaternate females were too scarce to insure adequate material for a microscopic examination.

The laying workers of the Cape honeybee, normally producing $100 \%$ female progeny in sufficient number, provide an excellent genetic system to study the cytological processes underlying female parthenogenesis in the honeybee by direct microscopic observation. Thus the aim of the present investigation is to work out the detailed cytological basis for automictic parthenogenesis in A.m. capensis.

\section{MATERIAL AND METHODS}

\section{Apis mellifera capensis Escholtz}

The Cape bee is the southernmost population of the African group of A.m. (RUTTNER, 1975). Morphologically it is characterized by medium size, dark body colour, a developed spermatheca in worker bees of about half the size of a queen's spermatheca and an increased number of ovarioles in the worker's ovaries (ANDERSON, 1963, RUTTNER, 1977). The pure type is restricted to the relatively small area of the Cape peninsula. In spite of the fundamental biological disparity, capensis is fully fertile if hybridized with other races of $A . m$.

The most conspicuous characteristic of the race is the faculty of worker bees to reproduce by thelytokous parthenogenesis. Due to this phenomenon, a queenless and broodless colony of Cape bees, in any other race destined to perish, is capable of self-preservation. A queen may be reared from parthenogenetically produced female larvae, which will take over the colony after mating. Curiously, a mated capensis queen produces female individuals from fertilized eggs and male individuals from unfertilized ones as is true in all other races. Assuming a higher loss of queens during the mating flight on the Cape peninsula, this type of reproduction could have a selective advantage (RUTTNER, 1977).

Queens of A.m. capensis were supplied by courtesy of Dr. R. H. Anderson, Plant Protection Research Institute, Stellenbosch, and of several beekeepers in the Cape Province, especially M. van Drummen, Grabow. A number of colonies of the Cape bee are being successfully kept in flight rooms and in the open for several years at 
the Institut für Bienenkunde, Oberursel, in spite of certain difficulties in overwintering. Mating is performed by instrumental insemination.

\section{Collection of eggs}

A satisfactory method of obtaining a large number of exactly dated eggs from laying capensis workers was developed. A brood comb from a laying capensis worker colony was placed in an incubator at $34{ }^{\circ} \mathrm{C}$ (it was found from experience that in the Cape bee the impaternate offsprings of laying workers are more prolific and vigorous in their egg laying capacity compared to those produced by capensis queen bees). 8-10 newly emerged capensis bees were individually marked and introduced into a small cage along with 50 young nurse bees of A.m. carnica. Previously it was shown that queenless carnica workers needed 30 days to develop their ovaries to the egg laying stage compared to 6 days with A.m. capensis (RUTTNER and HESSE, 1981); thus it was guaranteed that the eggs which would appear in the cage after 7-10 days originated from capensis workers. Laying workers of capensis act as "pseudoqueens" by producing a considerable amount of keto-2-decenoic acid (HEMmLING, KoENIGER and RUTTNER, 1978) and suppressing the development of the ovaries of the attendant bees. The one or several fertile capensis worker bees may lay as many as several hundred eggs in the cells of the little comb fixed in the cage.

The bees were kept in an incubator at $26 \pm 1{ }^{\circ} \mathrm{C}$ and were fed with sugar solution and pollen cake. To assure ample material during the entire experiment, 15 cages were maintained simultaneously.

The experiment was started with empty combs and the cages were examined through the glass walls for eggs every 30 minutes. The site of each egg was marked to obtain eggs of known ages. Thus it was possible to obtain a complete series of developing eggs with an accuracy of $\pm 15 \mathrm{~min}$.

\section{Cytological methods}

The slides of eggs were prepared by the squash technique for the chromosomal studies.

Mature ovaries of the laying worker bees (from bees that laid eggs for at least one week) were dissected in 0,7 \% BAKER's saline solution (BAKER, 1944). Before fixation, eggs or ovaries were pretreated with $0,9 \%$ sodium citrate or with $0.55 \mathrm{M}$ OHNUKI's solution (1965). The pretreated material was then fixed in acetic-alcohol and stained with the following stains.

1. Aceto-carmine (KitZMiller and Clark, 1952),

2. Aceto-orcein (DARLINGTON and LA COUR, 1976),

3. Lacto-acetic-orcein (SHEPPARD, 1973).

Eggs of different age groups (0-7 hours old) were also processed for sectioning. The eggs were fixed in Petrunkewitsch's fixative and the $5 \mu \mathrm{m}$ thick sections were stained with Heidenhains iron hematoxylin. 


\section{RESULTS}

The different events occuring in the egg during the time of the first and second maturation divisions are summarized in table 1. The times shown are approximate, but are corrected as closely as possible for $26^{\circ} \mathrm{C}$.

TABL.1. - Time co-relation of meiotic activities in the egg of Apis mellifera capensis laying worker bees before and after oviposition at $26^{\circ} \mathrm{C}$.

\begin{tabular}{|c|c|c|}
\hline $\begin{array}{l}\text { Time in relation } \\
\text { to oviposition }\end{array}$ & Stages of maturation division & Remarks \\
\hline Before oviposition & $\begin{array}{l}\text { 1) Growth of the Oocyte } \\
\text { 2) First maturation division starts } \\
\text { 3) Diakinesis and Metaphase I stages } \\
\text { observed with } 16 \text { bivalents } \\
\text { 4) Anaphase I spindle }\end{array}$ & $\begin{array}{l}\text { First meiotic division is reductio- } \\
\text { nal }(n=16) \\
\text { Anaphase I spindle is parallel to } \\
\text { the longitudinal axis of the egg }\end{array}$ \\
\hline Newly laid eggs. & $\begin{array}{l}\text { Anaphase I spindle present in the peri- } \\
\text { plasmic area at the anterior end of the } \\
\text { egg. }\end{array}$ & $\begin{array}{l}\text { Position of the anaphase I spindle } \\
\text { is as before oviposition }\end{array}$ \\
\hline $1 / 2$ to 1 hour & Telophase I & $\begin{array}{l}\text { Two nuclei formed which lie in } \\
\text { the same position as that of the } \\
\text { Anaphase I spindle }\end{array}$ \\
\hline 3 to 4 hours & $\begin{array}{l}\text { Anaphase II with two spindles in the } \\
\text { periplasmic area which is more ventral } \\
\text { to the anterior side of the egg }\end{array}$ & $\begin{array}{l}\text { Both the spindles are parallel to } \\
\text { the longitudinal axis of the egg }\end{array}$ \\
\hline 4 to $41 / 2$ hours & $\begin{array}{l}4 \text { haploid nuclei formed and two of } \\
\text { them fuse to form zygote }\end{array}$ & $\begin{array}{l}\text { Diploid number of chromosomes } \\
(2 n=32) \text { restored }\end{array}$ \\
\hline $41 / 2$ to 5 hours & $\begin{array}{l}\text { Zygote nucleus moved deeper into the } \\
\text { yolk area and the polar bodies degene- } \\
\text { rate }\end{array}$ & - \\
\hline 5 to 6 hours & First cleavage spindle & - \\
\hline After 6 hours & Blastoderm formed & $\begin{array}{l}\text { Diploid number of chromosomes } \\
(2 n=32) \text { in the somatic cells }\end{array}$ \\
\hline
\end{tabular}

\section{First maturation division}

The first maturation division occured before oviposition but no further divisions were seen until the egg was laid. The early stages of the first meiotic division were observed in the egg in the ovariole stalk and also in the oviduct where the eggs were lying free.

The different cytological events that occured in the eggs (before and after oviposition) as observed by the squash and microtomy techniques were as follows. 


\section{Prophase I}

The leptotene stage was characterized by an increase in size of the nucleus. During the zygotene stage, pairing between the homologous chromosomes occured as a result of synapsis. The pachytene stage (Fig. 1) was characterized by the pairing of the homologous chromatids, i.e. bivalents. During the diplotene stage (Fig. 2), the paired chromatids crossed over one another and these chromatid exchanges are called chiasmata. The diakinesis (Fig. 3) is the most prevalent and important stage found in most of the cells studied. The 16 bivalents were easily counted at this stage. Each bivalent usually contained two chiasmata. The clear presence of chiasmata in the bivalents indicated that the reductional division occured and that there was an exchange of genetic material between the two homologous chromosomes.
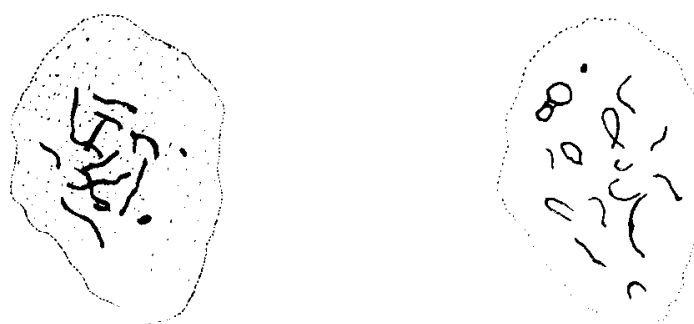

FIG. 1 and 2. - Stages of the first meiotic division from a developing oocyte of a laying worker of the Cape honeybee (Apis mellifera capensis)

\section{1 : Pachytene 2 : Diplotene}

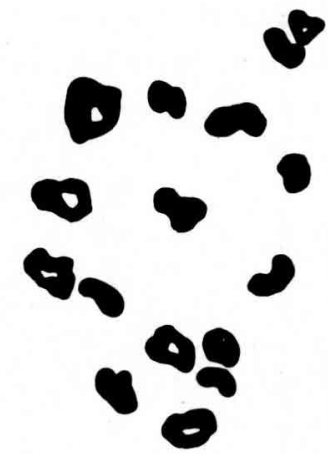

FIG. 3. - Diakinesis I, showing rounded bivalents.

At the end of the diakinesis, the nuclear membrane dissolved. However, the precise time at which the nuclear membrane disappeared could not be easily demonstrated because the presence of the yolk interfered with the observations. 
Metaphase I (Fig. 4)

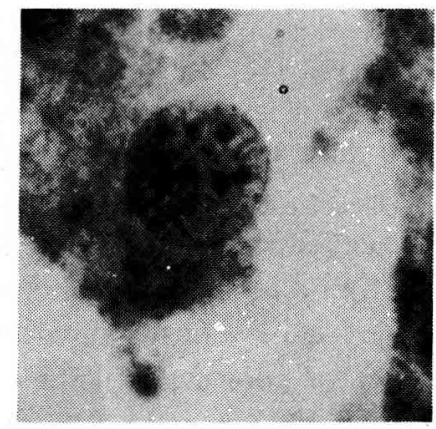

FIG. 4. - Metaphase I.

After the disappearance of the nuclear membrane, the bivalents became more condensed and compact. However, they still retained their V- or ring-shaped structures and were deeply stained. There were 16 bivalents as seen in the polar view.

\section{Anaphase I (Fig. 5)}

This stage was observed in eggs dissected from the oviducts of the laying worker bees or in newly laid eggs and could be confirmed by squash as well as by histological methods.

The orientation of the spindle was observed in tissue sections. In recently laid eggs the spindle fibres were arranged parallel to the longitudinal axis of the egg. The two poles of the spindle were clearly seen in many of the cells. At anaphase I, while the two chromosomal groups were still connected by spindle fibres (Fig. 5) one group was more compact than the other.

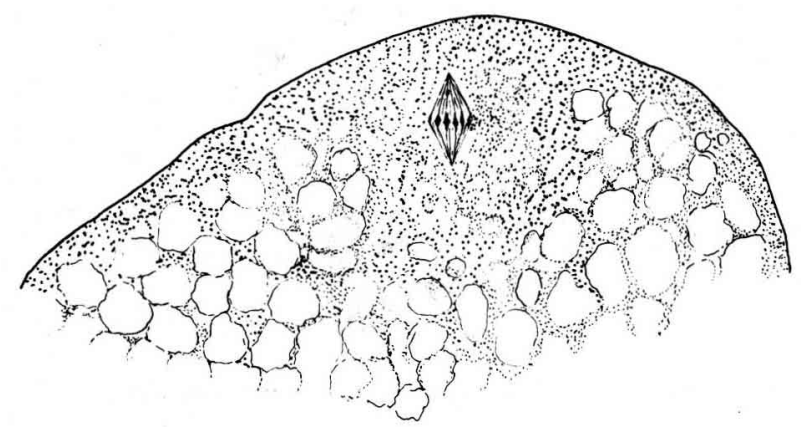

FIG. 5. - Anaphase I.

The first meiotic division occurred at the anterior end of the egg in the periplasmic area (the area free of yolk globules). 
The net result of the first meiotic division was the formation of 2 nuclei, the chromosomes of which were clumped together in the late anaphase I or telophase I stage (Fig. 6). The nuclear membranes also formed around these nuclei during the late telophase stage. On of the egg nuclei was larger than the other. The first maturation division resulted in the formation of one egg pronucleus and the first polar nucleus.

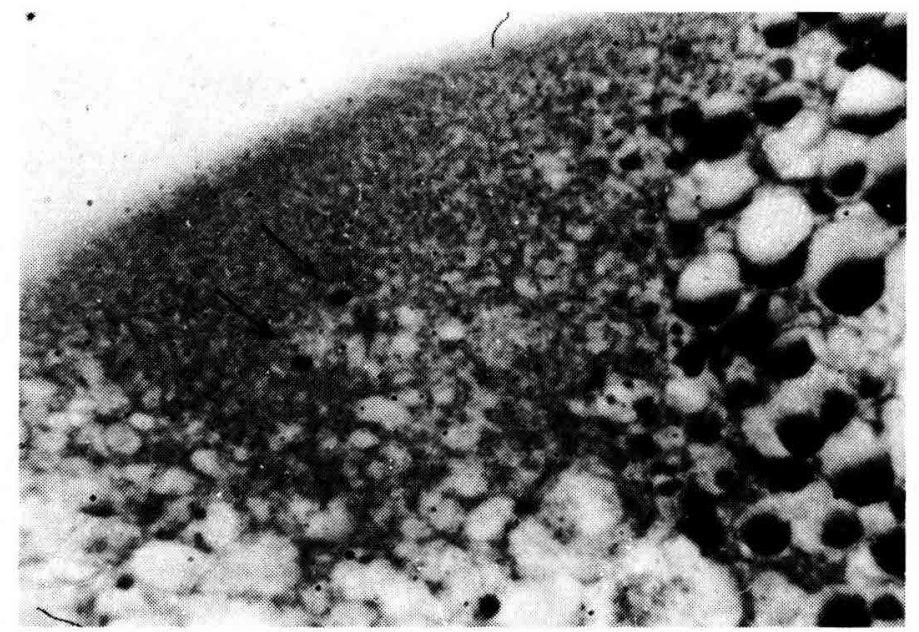

FIG. 6. - Telophase I.

Two nuclei (arrows).

Thus the chromosome number was reduced to half. The first maturation division was reductional and could be considered equivalent to that of the normal meiosis of a queen bee egg.

\section{Second maturation division}

In the present experiments, the metaphase II stage was not observed in any of the sections of the egg. Either this stage was of a very short duration or telophase I immediately procedes the anaphase II stage.

\section{Anaphase II (Fig. 7)}

The spindles of the second meiotic division were contiguous and appeared approximately in line with those of the first division spindles. In this way both pairs of spindles lay parallel to the longitudinal axis of the egg in the periplasmic area towards the antero-ventral side of the egg. 


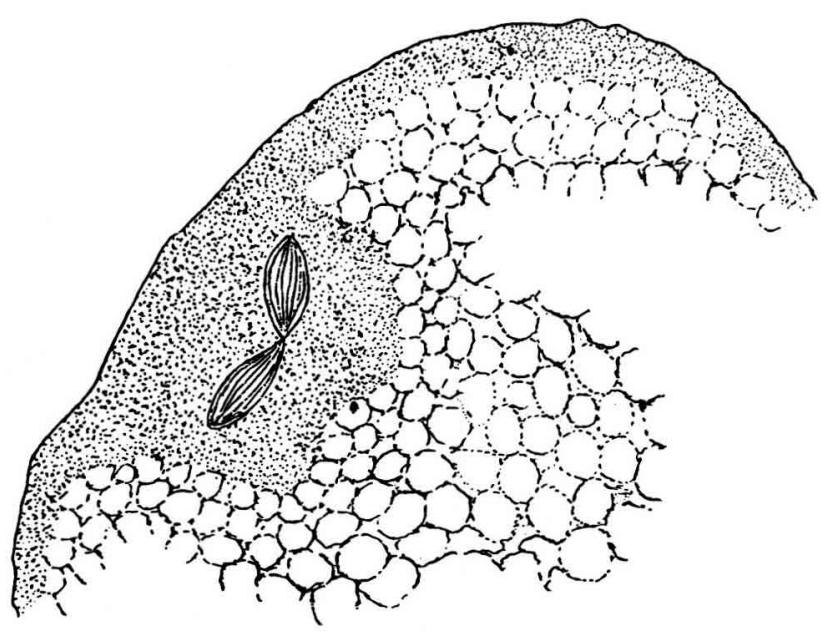

FIG. 7. - Second meiotic division : anaphase II.

Two spindles arranged in a single line and parallel to the egg axis.

The anaphase of the first maturation division could be distinguished from that of the second maturation division in several ways. For example, the periplasmic area was broader in anaphase II than in anaphase I. Anaphase II occured towards the antero-ventral side of the egg while the anaphase I occured in the anterior end of the egg and the spindle fibres in anaphase II were not as distinct and clear as in anaphase I.

\section{Telophase $I I$ (Fig. 8a, b)}

In 4- to 4 1/2-hour-old eggs, the resulting four haploid nuclei were arranged in the periplasmic area of the egg in the same manner as the anaphase II spindles. These nuclei were almost in a straight line and their position was also parallel to the longitudinal axes of the egg.

\section{Reconstitution of the diploid nucleus}

The second meiotic division resulted in the formation of 4 haploid nuclei. The one central nucleus which was larger in size than the other three, could be considered as the egg pronucleus. The egg pronucleus gave rise to the second polar nucleus which further divided but later degenerated. The first polar body of the egg pronucleus also divided into two, one fused with the egg pronucleus and the other moved towards the periphery and degenerated. Thus the zygote nucleus was formed by the fusion of the egg pronucleus and one of the descendants of the first polar body (union between two central nuclei).

The remnants of the polar bodies were observed on the periphery of the egg, while the ootid nucleus moved towards the centre. 


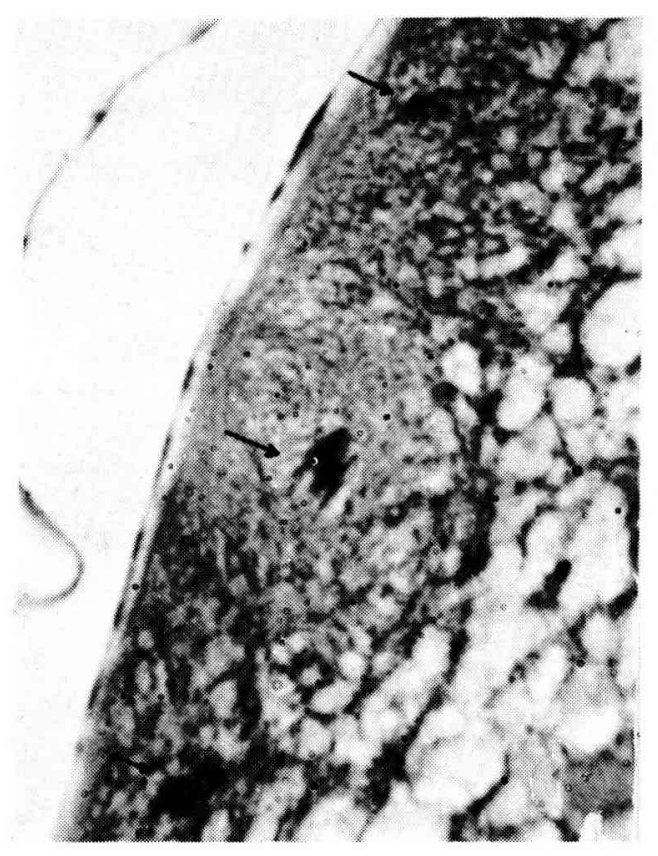

Fig. 8 a. - Telophase II.

A microphotograph showing 4 nuclei. Note the close proximity of the two central nuclei.

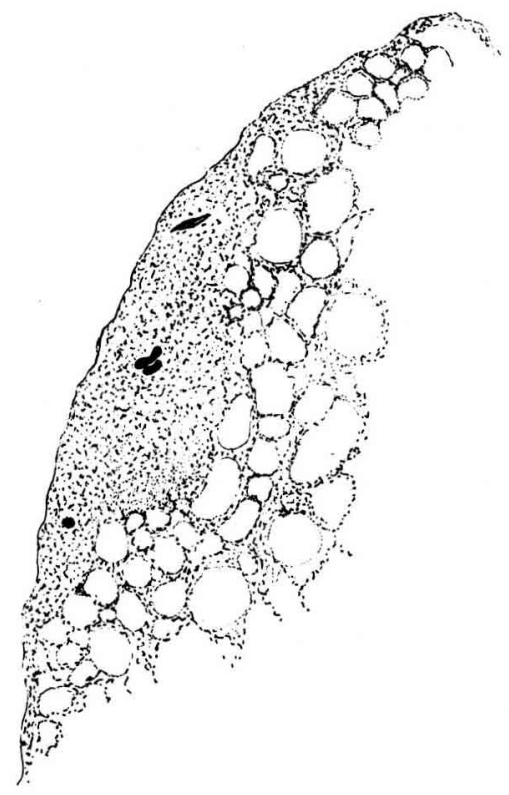

FIG. 8 b. - Telophase II.

Camera lucida drawing showing the two central nuclei distinctly separated. 


\section{Cleavage nuclei and somatic chromosomes}

The central zygote nucleus after a brief interphase moved to the centre of the egg (Fig. 9) where it formed first cleavage spindle (Fig. 10). However, it was not

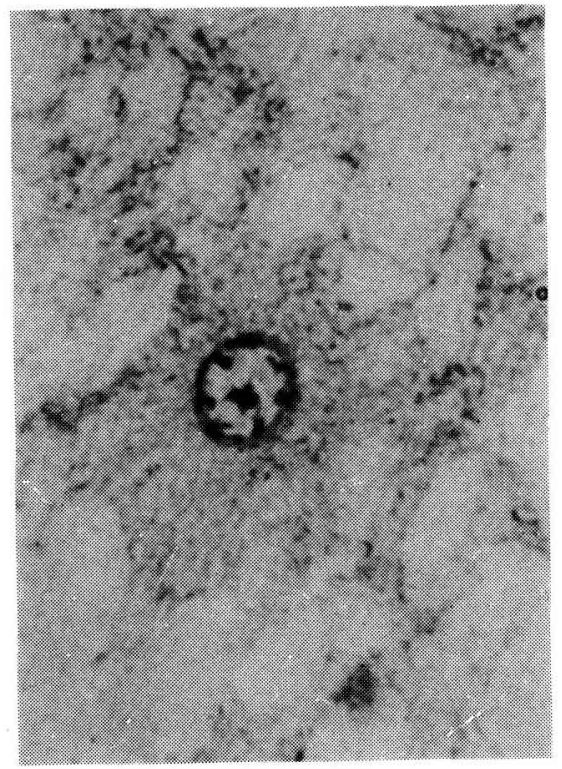

FIG. 9. - Zygote nucleus in the peripheral periplasmic region of the egg.

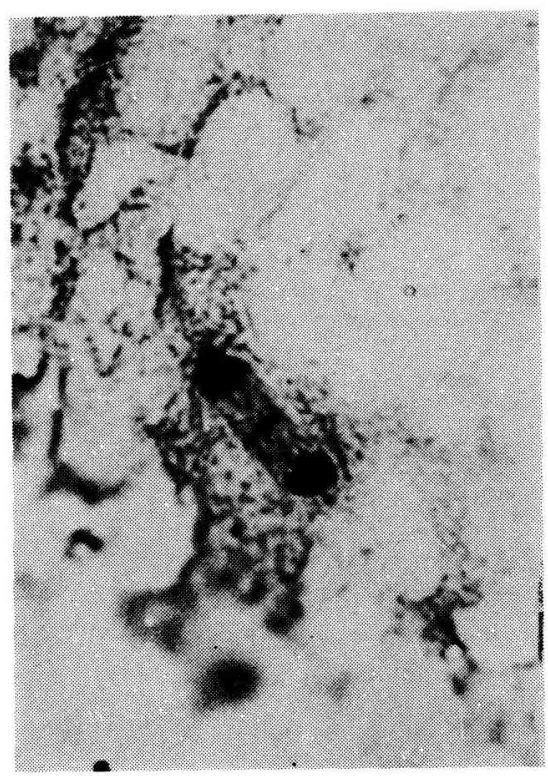

FIG. 10. - First cleavage spindle. 
possible to count the number of chromosomes at the first cleavage stages in the sections by tissue sections. But by squash preparations of the blastula stage cells formed in 6-hour old eggs, it was possible to observe the somatic metaphase and somatic anaphase stages of diploid cells.

Somatic metaphase (Fig. 11)

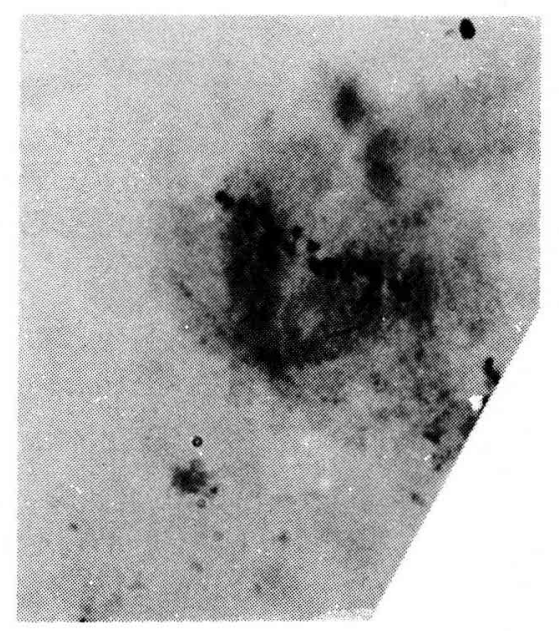

FIG. 11. - Somatic metaphase.

During this stage, all 32 chromosomes were deeply stained, and it was possible to count them accurately. This stage was observed in large numbers of cells.

\section{Somatic anaphase}

This stage was frequently observed in the blastodermal cells. The two groups of chromosomes on either side of the equator, each with 32 chromosomes, were clearly visible during this stage. These two stages confirmed the diploid number of chromosomes in the impaternate females. Later, the two chromosomal groups migrated to their respective poles and the two nuclei were evident in telophase.

\section{DISCUSSION}

In developing embryos from laying workers of capensis bees, the somatic metaphase stages obtained from blastoderm cells revealed the diploid number $(2 n=32)$ of chromosomes. These cytological observations confirmed the previous genetic results of MACKENSEN (1942), BUTLER (1954) and TUCKER (1958) who also reported that impaternate females of different races of Apis mellifera are diploid. 
In discussing parthenogenesis in the capensis bee, it is important to know if the production of diploid progeny by laying worker bees involves ameiotic chromosomal behaviour with no chromosome reduction or if there is some type of meiosis with the restitution of diploid chromosomal complements. Earlier genetic experiments by TUCKER (1958) and RUTTNER (1977) suggested an automictic type of parthenogenesis in which chromosomal reduction occured with restitution of the diploid chromosome complement. However, all these authors made their cytogenetic conclusions by genetic results, and not by direct cytological observations.

From the present cytological experiments, it was clear that the production of diploid progeny from the unfertilized eggs of Apis mellifera capensis worker bees, involved a meiotic mechanism in which the reduction of chromosome number does occur.

This conclusion was supported by the occurence of the normal meiotic stage in which chromosomal pairing, synapsis, crossing over and formation of bivalents were observed in diakinesis and metaphase I stage (Fig. 4).

The association of homologous chromosomes at diakinesis or early metaphase I was usually due to the presence of chiasmata, which in turn were either the result of previous interchange of chromatin material or occured prior to it. This further supports the view that reduction division occurs during meiosis in A.m. capensis laying worker bees. Other invertebrate species, in which automictic parthenogenesis is the mode of reproduction, also show chiasmata during diakinesis or the prophase stage of meiotic division (ThOMSEN 1927, SмIтн 1941, DodDs 1939, RösSLER and DE BACH 1973).

In the present investigation, 4 haploid nuclei were formed as a result of two meiotic divisions (Fig. 8). These 4 haploid nuclei simply occurred in the form of a chromatin mass with no surrounding cytoplasm or membrane. Three of these nuclei can be named as the polar nuclei and one, the central nucleus as the egg pronucleus. These nuclei are arranged in a row parallel to the longitudinal axis of the egg. Later, two central nuclei, i.e. the egg pronucleus and the descendant of the first polar body (second division non-sister nuclei), fuse to form the zygote nucleus, and the other two terminal nuclei degenerate. In the honeybee queen, the female egg pronucleus migrates deeper into the interior of the egg and fuses with the sperm nucleus to form the zygote nucleus. At the same time, two polar bodies near the periphery of the egg also fuse and orm the Richtungskopulationskern (RKK) which undergoes a meiotic division and eventually degenerates (PETRUNKEWITSCH 1901, NACHTSHEIM 1913). The zygotic nucleus observed in our sections (Fig. 9) was comparable to the formation of the RKK with a slight modification : instead of one of the polar nuclei, the egg pronucleus fused with the descendant of the first polar body. 
A similar formation of a RKK, by the union of two central nuclei formed as a result of normal meiosis in automictic forms of parthenogenesis, has also been reported in other invertebrate species (NARBEL-HOFSTETTER, 1964) and formation of RKK is possibly a pre-adaptation to the automictic type of parthenogenesis.

Based on his genetic experiments, TUCKER (1958) put forward a hypothesis of spindle misorientation scheme in order to explain the nature of fusion of nuclei for the restoration of diploidy in the impaternate females in different races of Apis mellifera. Ordinarily, the first meiotic spindle in the newly laid eggs of the honeybee lies in a sagittal plane, parallel to the surface of the egg. But later at anaphase I stage, the spindle rotates through $90^{\circ}$ and occupies a position perpendicular to the surface of the egg (Fig. 12 A; Petrunkewitsch 1901, NACHTSHEIM 1913).

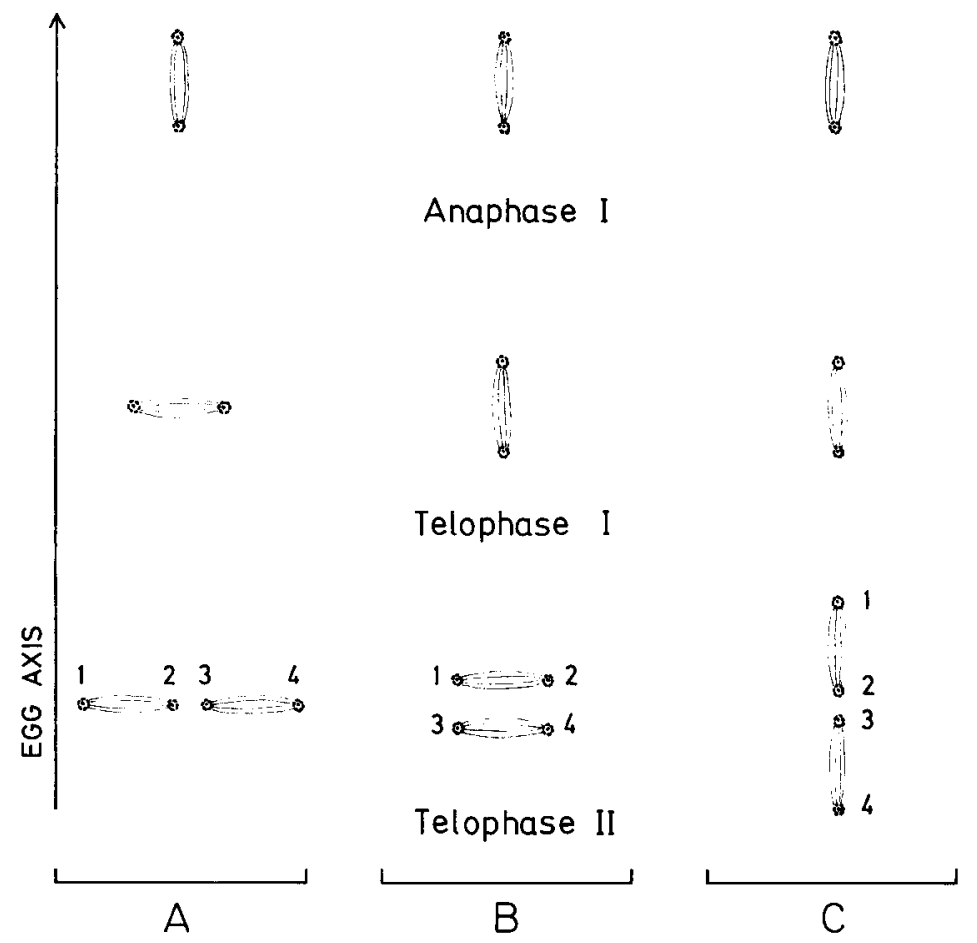

FIG. 12. - Scheme of meiotic spindle orientation in biparental and thelytokous reproduction of honeybees ( 1 and 2 descendant of first polar body; 3 egg pronucleus; 4 polar body 2 ).

A : Normal meiosis in the queen honeybee (Petrunkewitsch, 1901 and Nachtsheim, 1913).

B : Hypothetical spindle misorientation scheme for thelytokous queens and worker bees (TUCKER, 1958).

$\mathrm{C}:$ The actual position of spindles during maturation divisions in the laying workers of Apis mellifera capensis as observed in the present cytological investigations. 
However, according to TUCKER (1958), the first meiotic spindle failed to rotate in the eggs, due to automictic development, and the first division was completed while the spindle was still parallel to the surface of the egg (Fig. $12 \mathrm{~B}$ ). The second division spindles of the two secondary oocytes may then be far enough apart to form on two separate axes projecting into the egg. As a result, at metaphase II and anaphase II stages, the two nuclei 2 and 4 facing the interior of the egg would unite, while the other two, 1 and 3 towards the periphery, would degenerate (Fig. $12 \mathrm{~B}$ ). In this way, two central nuclei 2 and 4 from two different oocytes would unite.

In the present investigations, no rotation in the position of the spindle was observed and its orientation (parallel to the longitudinal axis of the egg) was the same both before and after oviposition (Fig. 5, 8). Even after the second meiotic division, two spindles were seen in the sagittal plain, parallel to the surface of the egg as they were in the first meiotic division spindle (Fig. 8, 12 C). TUCKER (1958) explained that the two spindles after the second maturation division may lie perpendicular to the longitudinal axis of the egg but parallel to one another (Fig. 12 B). Our cytological results showed that the second maturation spindles lie in a straight line one above the other as a result of which 4 haploid nuclei were arranged in a row parallel to the longitudinal axis of the egg (Fig. $8 a, 8 b, 12 \mathrm{C}$ ).

Thus, our cytological investigations confirm the genetic results of $\mathrm{K}$. TUCKER (1958) who showed segregation of genes in parthenogenetic reproduction, but they reveal another cytological mechanism as hypothetically proposed by this author.

In the thelytokous A.m. capensis, two non-sister nuclei unite by central fusion. It is of interest to note that a different cytological process occurs in the thelytoky of another Hymenopteran, Aphytis mytilaspidis (Aphelinidae). According to RöSSLER and DE BACH (1973) after meiosis I, with the formation of chiasmata, one nucleus advances in development in meiosis II and degenerates later during anaphase. The other (peripheral) nucleus starts anaphase II but it was impossible to analyse further cytological events. Nevertheless, it was concluded from the genetic consequences (segregation of heterozygotic genes) that anaphase of the haploid products was completed, followed by fusion of the two sister nuclei (terminal fusion).

Both methods of restoration of the diploid condition have as a consequence the recombination of genes. Central fusion tends to maintain the initial heterozygosity but transferred segments of chromosomes during chiasmata become homozygote, and terminal fusion tends to homozygosity, except for loci which undergo crossover.

Thelytoky in the Cape bee is modified by fertilization and caste differences. The eggs laid by mated capensis queens develop to biparental diploid females if fertilized and to uniparental haploid males if unfertilized. Whether mated capensis queens produce a higher percentage of thelytokous worker bees than 
queens of other races was not investigated. Unpublished experiences with capensis queens heterozygous for recessive marker genes indicate however that this event is certainly not frequent.

That there is a considerable environmental influence on meiosis has to be assumed because virgin capensis queens laying unfertilized eggs (induced by narcosis with $\mathrm{CO}_{2}$ ) produce diploid females and haploid males in varying proportion.

In addition the different types of parthenogenesis in other animals and the cytological processes to restore or maintain diploidy in reproduction show a high degree of variability.

Received for publication in October 1982.

\section{ACKNOWLEDGEMENTS}

We wish to thank the staff of the Institut für Bienenkunde Oberursel for providing all technical help for these investigations; Mrs. Ingeborg SANDER assisted with special skill in producing dated eggs of laying capensis workers. We are indebted to Dr. L. R. Verma (Himachal Pradesh University, Simla) for critically reading this manuscript.

The senior author thanks for financial assistance from D.A.A.D., Bonn.

\section{ZUSAMMENFASSUNG}

\section{ZYTOLOGISCHE ANALYSE DER THELYTOKEN PARTHENOGENESE} BEI DER KAPBIENE (APIS MELLIFERA CAPENSIS ESCHOLTZ)

Bei der südafrikanischen Kapbiene entstehen aus Eiern, die von Arbeitsbienen abgelegt worden sind, nicht Drohnen, wie bei den anderen Rassen von Apis mellifera, sondern weibliche Tiere (Arbeiterinnen oder Königinnen). Die zytologische Grundlage dieses Phänomens wurde untersucht.

\section{Material und Methode}

Im Brutschrank geschlüpfte Jungbienen der Kapbiene (8-10 Individuen) wurden zusammen mit 50 jungen Arbeiterinnen der Rasse carnica in mit einem Wabenstück versehenen Käfigen bei $26^{\circ} \mathrm{C}$ gehalten und mit Zuckerlösung und Pollenteig gefüttert. Da weisellose Kap-Arbeiterinnen sehr viel früher mit der Eiablage beginnen als carnica-Arbeiterinnen (nach 6-7 Tagen gegen 30 Tagen), konnte man sicher sein, daß die abgelegten Eier von Kapbienen stammten. Die Käfige wurden alle 30 Minuten kontrolliert, die frisch mit einem Ei belegten Zellen markiert und die Eier nach dem jeweils gewünschten Intervall (0-7 Stunden) entnommen.

Die zytologische Untersuchung erfolgte entweder an Quetschpräparaten (Fixierung in Essigsäure-Alkohol nach Vorbehandlung in Natriumzitrat, Färbung mit Karmin- oder Orcein-Essigsäure) oder an Paraffinschnitten nach Fixierung in Petrunkewitsch-Gemisch und nachfolgender Färbung in Heidenhains Lösung. 


\section{Ergebnisse}

Der Ablauf der beiden Reifeteilungen entspricht bis zur Anaphase I ganz dem, wie er von früheren Autoren von Eiern beschrieben wurde, die von einer Königin abgelegt wurden (Tab. 1; Fig. 1-7). Zum Zeitpunkt der Eiablage befindet sich der Eikern im Stadium Anaphase I.

In Telophase II sind vier Kerne zu sehen, in einer geraden Linie parallel zur Eioberfläche angeordnet (Fig. $8 a, b$ ). Von den beiden inneren Kernen entspricht der eine (Fig. 12, Nr. 3) dem Eivorkern, der andere (Nr. 2) einem Tochterkern von Polarköper 1. Diese beiden Kerne verschmelzen in der Folge und bilden den diploiden Eikern (zentrale Fusion), der in die Tiefe wandert und dort die Furchungsteilungen einleitet (Fig. 10, 11).

Der Unterschied gegenüber dem normalen Ablauf der Meiose bei einem von der Königin stammenden Ei besteht darin, daß die Rotation der Teilungsspindel um $90^{\circ}$ in Meiose $I$ unterbleibt (Fig. $12 \mathrm{~A}$ ) und daß nicht zwei Polkörper miteinander zum " Richtungskopulationskern " verschmelzen, um dann zu Grunde zu gehen, sondern daß Kern Nr. 2 mit dem Vorkern (Nr. 3) verschmilzt und damit den diploiden Kern der Zygote bildet.

\section{RÉSUMÉ}

\section{ANALYSE CYTOLOGIQUE DE LA PARTHENOGENĖSE THELYTOQUE CHEZ L'ABEILLE DU CAP (APIS MELLIFERA CAPENSIS ESCHOLTZ)}

Chez l'abeille du Cap (Afrique du Sud) les cufs pondus par les ouvrières donnent naissance, non pas à des mâles comme chez les autres races d'Apis mellifera, mais à des femelles (ouvrières ou reines). On a étudié les bases cytologiques de ce phénomène.

\section{Matériel et méthodes}

On a maintenu à $26^{\circ} \mathrm{C}$, avec 50 ouvrières de la race carnica dans des cages munies d'un morceau de rayon, de jeunes abeilles du Cap ( 8 à 10 individus) nées en étuve et on les a nourries avec du sirop et une pâte de pollen. Puisque des ouvrières du Cap orphelines commencent à pondre beaucoup plus tôt que des ouvrières carnica (au bout de 6 à 7 jours contre 30 jours), on est certain que les aufs pondus proviennent bien des ouvrières du Cap. On a contrôlé les cages toutes les $30 \mathrm{mn}$, marqué les cellules fraîchement pourvues d'un œuf et prélevé les œufs au bout de l'intervalle de temps souhaité, qui a varié de 0 à 7 heures.

L'étude cytologique a été faite soit sur des préparations par écrasement (squash) avec fixation dans un mélange alcool-acide acétique après traitement au citrate de sodium et coloration au carmin acétique ou à l'orcéine acétique, soit sur des coupes à la paraffine après fixation dans le mélange Petrunkewitsch suivie de coloration dans une solution de Heidenhains.

\section{Résultats}

Le déroulement des 2 divisions de maturation correspond entièrement jusqu'à l'anaphase I à celui que les auteurs antérieurs ont décrit pour des œufs pondus par une reine (Tabl. 1, Fig. 1-7). Au moment de la ponte le noyau ovulaire se trouve au stade de l'anaphase $I$.

A la télophase II on peut voir 4 noyaux rangés selon une ligne droite parallèle à la surface supérieure de l'œuf (Fig. 8 a et b). Les 2 noyaux internes correspondent l'un au pronucleus (Fig. 12, no 2), l'autre au noyau -fils du ler corps polaire (Fig. 12, no 2). Par la suite ces 2 noyaux fusionnent et forment le noyau ovulaire diploïde (fusion centrale), qui migre au centre et y entame la division de segmentation (Fig. 10 et 11 ).

La différence par rapport au déroulement normal de la méiose chez un æuf pondu par une reine consiste en les points suivants : la rotation de $90^{\circ}$ du fuseau n'a pas lieu à la $1^{\text {re }}$ méiose (Fig. $12 \mathrm{~A}$ ); 2 corps polaires ne fusionnent pas ensemble en un "noyau d'accouplement polaire " pour disparaître ensuite, mais le noyau $n^{\circ} 2$ fusionne avec le pronucleus $\left(n^{\circ} 3\right)$ et constitue ainsi le noyau diploïde du zygote. 


\section{REFERENCES}

ANDERSON R. H., 1963. - The laying worker in the Cape honeybee, Apis mellifera capensis. J. apic. Res., 2, 85-92.

BAKer J. R., 1944. - Cytological techniques. 2nd ed. London, Methuen.

BUTLER C. G., 1954. - The world of the honeybees. London, Collins.

Crozier R. M., 1977. - Evolutionary genetics of the hymenoptera. Ann. Rev. Entomol., 22, 263-268.

Darlington C. D., LA-Cour L. F., 1976. - The handling of the chromosomes. 3rd ed. London, Allen and Unwin.

FAHRnhorst H., 1977. - Chromosome number in the tropical honeybee species Apis dorsata and Apis florea. J. Apicult. Res., 16, 56-58.

Gubin A. F., Khalifman I. A., 1951. - (Queen rearing from drone eggs) Agrobiologiya, 1, 99-104. (In Russian.)

Hemmling C., Koeniger N., RutTNer F., 1979. - Quantitative Bestimmung der 9-Oxodecensäure im Lebenszyklus der Kapbiene (Apis mellifera capensis Esch.). Apidologie, 10, 227-240.

JACK R. W., 1916. - Parthenogenesis amongst the workers of the Cape honeybee. Mr. G. W. Onions experiments. Trans. Roy. Ent. Soc. London, 1916, 393-406.

Kitzmiller J. B., Clark G. L., 1952. - Salivary gland chromosomes in Culex mosquito. Genetics, 37, 596.

MACKENSEN O., 1943. - The occurence of parthenogenetic females in some strains of honeybees. J. econ. Entomol., 36, 465-670.

NaChTSheim H., 1913. - Cytologische Studien über die Geschlechtsbestimmung bei der Honigbiene (Apis mellifera L.). Arch. Zellforsch., 11, 169-241.

NARBel-Hofstetter M., 1964. - Les altérations de la méiose chez les animaux parthénogénétiques. Protoplasmatologia VI/F/2. Vienna, Springer-Verlag.

OHNuki Y., 1965. - Demonstration of the spiral structure of human chromosomes. Nature, 208, 916-917.

Onions G. W., 1912. - South African fertile worker bees. Agric. J. Union S. Africa, 3, 720-728.

ONions G. W., 1914. - South African " fertile worker bees" Agric. J. Union S. Africa, 7, 44-46.

Petrunkewitsch A., 1901. - Die Richtungskörper und ihr Schicksal im befruchteten und unbefruchteten Bienenei. Zool. Jahrb. Abt. Anat. Ontogen. Tiere, 14, 573-608.

Rössler Y., De BACH P., 1973. - Genetic variability in a thelytokous form of Aphytis mytilaspidis (Le Baron) (Hymenoptera : Aphelinidae). Hilgardia, 42, 149-176.

RutTNER F., 1975. - African races of honeybees. Proc. 25. Intern. Apimondia Congr., 325-344, Bucharest.

RUTTNER F., 1977. - The problem of the Cape bee (Apis mellifera capensis Esch.) : Parthenogenesis-size of population-evolution. Apidologie, 8, 281-294.

RUtTNER F., HeSse B., 1981. - Rassenspezifische Unterschiede in der Ovarentwicklung und Eiablage von weisellosen Arbeiterinnen der Honigbiene Apis mellifera L. Apidologie, 12, 159-183.

Sheppard P. M., 1973. - Practical genetics. London, Blackwell Saint Publ.

SUOMALAinEN E., 1961. - On morphological differences and evolution of different polyploid parthenogenetic weevil populations. Hereditas, 47, 309-341.

TRYASKo V. V., 1969. -- Study of spontaneous female parthenogenesis in honeybees. Proc. Apimondia Congress München, Bucharest, 599.

Tryasko V. V., 1975. - Cytologic mechanism of female parthenogenesis in honeybees. Proc. 25th Apimondia Congress Grenoble, Bucharest, 318.

TUCKER K. W., 1958. - Automictic parthenogenesis in the honeybee. Genetics, 43, 299-316. 